\title{
A UNIFIED TECHNOLOGY OF CRUST LEATHER PRODUCTION USING POLYMERIC COMPOUNDS DEVELOPMENT
}

\author{
Nataliia PERVAIA, Olga ANDREYEVA, Lesia MAISTRENKO, Olena MOKROUSOVA, Svitlana HARKAVENKO, \\ Anna NIKONOVA
}

Kyiv National University of Technologies and Design, 2 Nemyrovycha-Danchenka Str., 01011, Kyiv, Ukraine, nataliiapervaia@gmail.com

Received: 23.06.2019

Accepted: 23.09.2019

https://doi.org/10.24264/Ifj.19.3.4

\section{A UNIFIED TECHNOLOGY OF CRUST LEATHER PRODUCTION USING POLYMERIC COMPOUNDS DEVELOPMENT}

ABSTRACT. Nowadays there is a considerable deficit of extractive, material and energy resources. Thus, there is a topical issue of creating, developing and application of ecologically friendly, resource-saving technologies of natural leather development, using modern materials, which are able both to replace toxic reactive chemicals, fully or partially, and maintain the high quality of products. We have developed a standardized technology of crust leather production regarding the tanning and crusting processes, using ecologically friendly polymeric compounds of the new generation. This technology provides a more sustainable use of leather raw materials and chemicals, decreasing the processing length and environmental harm.

KEY WORDS: crust leather, standardized technology, tanning, crusting processes, polymeric compounds

\section{O TEHNOLOGIE UNIFICATĂ DE FABRICARE A PIELII CRUST UTILIZÂND DEZVOLTAREA COMPUȘILOR POLIMERICI}

REZUMAT. În prezent, există un deficit considerabil de resurse extractive, materiale și energetice. Astfel, există o problemă de actualitate privind crearea, dezvoltarea și aplicarea tehnologiilor ecologice, care să ducă la economisirea resurselor pentru fabricarea pielii naturale, folosind materiale moderne, care sunt capabile să înlocuiască integral sau parțial substanțele chimice reactive toxice și să mențină calitatea ridicată a produselor. S-a dezvoltat o tehnologie standardizată de producție a pielii crust cu privire la procesele de tăbăcire și prelucrare a pielii în stadiul crust, folosind compuși polimeri ecologici din noua generație. Această tehnologie oferă o utilizare mai durabilă a materiilor prime și a substanțelor chimice în prelucrarea pielii, reducând durata prelucrării și prejudiciul adus mediului.

CUVINTE CHEIE: piele crust, tehnologie standardizată, tăbăcire, procese de prelucrare a pielii crust, compuși polimerici

LE DÉVELOPPEMENT DE LA TECHNOLOGIE UNIFIÉE DE LA PRODUCTION DU CUIR EN CROÛTE EN UTILISANT DES COMPOSÉS POLYMÈRES RÉSUMÉ. Il existe actuellement un déficit considérable de ressources extractives, matérielles et énergétiques. Ainsi, il y a un problème actuel concernant la création, le développement et l'application de technologies de développement du cuir naturel respectueuses de l'environnement et de l'économie, utilisant des matériaux modernes et capables de remplacer totalement ou partiellement les produits chimiques toxiques et réactifs, et de maintenir la haute qualité des produits. Nous avons développé une technologie standardisée de production de cuir en croûte en ce qui concerne les étapes de tannage et de finissage liquide, en utilisant des composés polymères écologiques de la nouvelle génération. Cette technologie permet une utilisation plus durable des matières premières et des produits chimiques pour le cuir, réduisant ainsi la durée de traitement et les dommages environnementaux.

MOTS CLÉS : cuir en croûte, technologie unifiée, tannage, finissage liquide, composés polymères

\section{INTRODUCTION}

Natural leather products have been in high demand for centuries due to such crucial properties as durability, reliability, excellent hygienic properties and attractive visual appearance. To ensure that products had these properties, common leather production technologies applied lengthy leather processing procedures and made extensive use of a range of chemicals, including harmful ones for the environment (e.g. sulphides, mineral and synthetic tanning agents, surface-active substances, dyes, organic solvents etc.) [1-3].

Natural leather is a product of consequent changes and transformations of collagen fibrous structure (collagen is a basic protein of animal skin) [4-5] when running various physicochemical processes and mechanical operations. Distinctive polyfunctional collagen structure allows to purposefully transform its structure during technology processing, influencing the product's (leather) functional performance and quality level.

Ecological safety of natural leather is a complex index. It ensures the absence of harmful impact on a human and the environment during the production, exploitation and disposal of goods. Technology processes of leather production play an important part in assuring the safety of leather materials. Sustainability of these processes means a clear understanding of collagen structure, justified choice and use of 
chemicals, minimizing waste and the amount of discharged water $[6,7]$.

Collagen structure constantly changes during technology processes. This means the destruction of existing links or the formation of new ones, as well as formation of spatial structure and properties of the derma [8]. Tanning plays a very important part here. Tanning is characterized by resistance to high temperature (hydrothermal resistance), microorganisms, shrinking (decreasing of the area), as well as an increase in porosity and its fixation when drying, increase in durability, elongation and deformability [9]. Nowadays $80-90 \%$ of common leather production technologies involve tanning with chrome compounds, and extra aftertanning derma structure formation takes place with the help of vegetable tanning agents and those of synthetic origin. Chrome tanning agent use provides excellent physico-mechanical and hygienic properties of natural leather with an appropriate level of hydrothermal and biological resistance [9]. Although tanning is one of the most important processes of leather production, it cannot be considered fully sustainable. This is due to the fact that chrome compounds in solutions are not completely absorbed: approximately $40 \%$ of chrome compounds end up in discharged water, which means it needs extra purification. Other drawbacks of chrome tanning are the problem of chromecontaining waste, non-constant properties of chrome compounds during continuous storing, a possible formation of hexavalent chrome. They try to overcome these drawbacks with the help of partial replacement of chrome compounds with other mineral or organic tanning agents, optimizing tanning parameters, multiple uses of tanning solutions, introducing masking off alkali reactive chemicals etc. Taking chrome compounds toxicity into account, there has long been systematic scientific and technological research on replacing these reactive chemicals with more ecologically friendly ones. Despite many works being written in this area of research [10-16], this kind of research is still topical due to the wide assortment of leather materials available.

Crusting processes are aimed at capillaryporous structure fixation of raw material being tanned. Despite the fact that the range of chemicals available for retanning, filling, fatting and dying is wide enough in terms of quantitative and qualitative indices, it is their combined and consecutive administration into one hydraulic liquid that allows for more sustainable use of water and effective bonding with collagen. Such an approach determines a decrease in environmental harm level and quality condition of industrial sewage after dying-fatting processes [10-16].

Thus, natural leather production is a complex technology process, based on numerous consecutive raw material and semifinished product processing. Various chemicals and substances, which are not completely safe, neither for the environment nor for a human, are used at each stage of a technology cycle. However, the fact that their use is inevitable means the need for more effective impact on the derma structural changes, as well as for reaching high functional performance and quality indices.

Chemicals being used and technological peculiarities of their use determine the safety level of natural leather during their whole life cycle: from production to consumption and utilization. Hence, the analysis of ecological aspects of leather production and of innovative technologies of harmful environmental impact reduction allows us to introduce the guidelines on the formation of safe natural leather for a modern consumer. The research done in this paper is devoted to these issues.

\section{EXPERIMENTAL}

\section{Materials and Methods}

\section{IR-Spectroscopic Method}

We have used an IR-spectroscopic analysis done with a TENSOR 37 spectrophotometer (Brucer, Germany) [17-19] to find the optical density of absorption bands and to identify functional groups of polymeric compounds.

\section{Colorimetric Method}

We have used a spectral optical device ULAB 102UV (China) to find the content of chrome compounds in exhausted solutions. Its spectral range of visible and ultraviolet radiation is 200$1000 \mathrm{~nm}$; the tolerance of the transmission ration is $\pm 0.1 \%$; the tolerance of the determination 
of the wave length is $\pm 1.5 \mathrm{~nm}$. The operational principle is based on the determination of the optical density of the absorption of thermal radiation of transparent solutions, taking into account the typical wavelength of the substance under study [20].

\section{Microscopical Method}

The impact of chrome-polymeric tanning on the change of the supramolecular structure of the derma collagen and the way of sedimentation of the chrome tanning agent in the supramolecular structure have been studied with the help of scanning electronic microscopy (SEM) using the device JSM-6490-LV, GEOL (Japan). This method is based on the study of the microobject surface structure by analysing the reflected "electronic image", which helps to monitor the structural elements peculiarities on the atomic-molecular level with high resolution of $1-5 \mathrm{~nm}\left(\times 10-\times 10^{-5}\right)[21]$.

\section{Crust Leather Properties Study Methods}

Physico-mechanical trial runs and the chemical analysis of the Crust leather have been done using the official IULTCS methods: sampling location (ISO 2417:2016), sample preparation and conditioning (ISO 2419:2012), shrinkage temperature (ISO 3380:2015), strength of surface (ISO 3379:2015), strength and percentage extension (ISO 3376:2011), apparent density (ISO 2420:2002), measurement of thickness (ISO 2589:2016), measurement of area (ISO 11646:2014), determination of tear load (ISO 3377-1:2011), water vapour permeability (ISO 14268:2012).

Reliability of the empirical data obtained is proved by the methods of mathematical statistics (average quadratic variation, multicriteria generalized objective function $\mathrm{Yg}$ ) [22]. The margin of error of the test when studying physico-mechanical properties was at most 5\%, the one of chemical composition indices was at most $3 \%$.

\section{The Study of Physico-Chemical Properties of Sustainable Polymeric Compounds}

Nowadays polymeric compounds play the most important part in natural leather production. They can be used effectively in liquid physico-chemical processes to form the structure and the most important properties of the derma [23-29]. Polymeric compounds include modern polymers based on unsaturated maleic and acrylic acids, which are able to interact with collagen and other materials, common in the production, such as tanning compounds. These acids are also capable of shortening the process cycle, providing a high level of work solution exhaustion, thermal stability, durability and plastic-elastic leather properties [30-32].

In order to develop the universal resourcesaving production technology of the Crust leather of chrome-polymeric tanning we have used a range of modern polymeric compounds, which are the certified products of CODYECO S.p.A. company (Italy). They are the derivates of unsaturated maleic (MA) and acrylic (AA1, AA2) acids. They are non-toxic, highly water-soluble and resistant to the activity of anionic electrolytes [33]. Their structure includes alkanes, alkenes, reactive carboxylic and hydroxylic groups etc.

To replace pickling by polymeric processing, we first studied the effect polymers (unsaturated carboxylic acids derivates) have on the properties of the abated pelt. Processing parameters are the following: polymers consumption (products $M A, A A 1$ and $A A 2) 2.0 \%$ of the pelt mass, the temperature is $36-38^{\circ} \mathrm{C}$, the duration is 1.5 hours. The $\mathrm{pH}$ level of solutions was for $M A 6.6$, for $A A 1$ - 5.3, for $A A 2-4.5$, for chrome tannin - 3.0. The control group specimens have been pickled before tanning. The test showed that after polymeric processing hydrothermal resistance of the pelt rose by $2-5^{\circ} \mathrm{C}$, while the tanning process duration fell by 2 times (figure 1). The results obtained can be explained with the effect created by processing conditions, the manner of sedimentation in the collagen structure of the reactive chemicals applied, and the manner of collagen structuring. Due to its chemical nature and physico-chemical properties, polymeric compounds are capable of influencing the tanning process, the structure formation and the Wet-Blue parameters. Taking the data obtained into account, we have conducted further research into the patterns of pickling-free chrome-polymeric tanning using this polymeric material. 


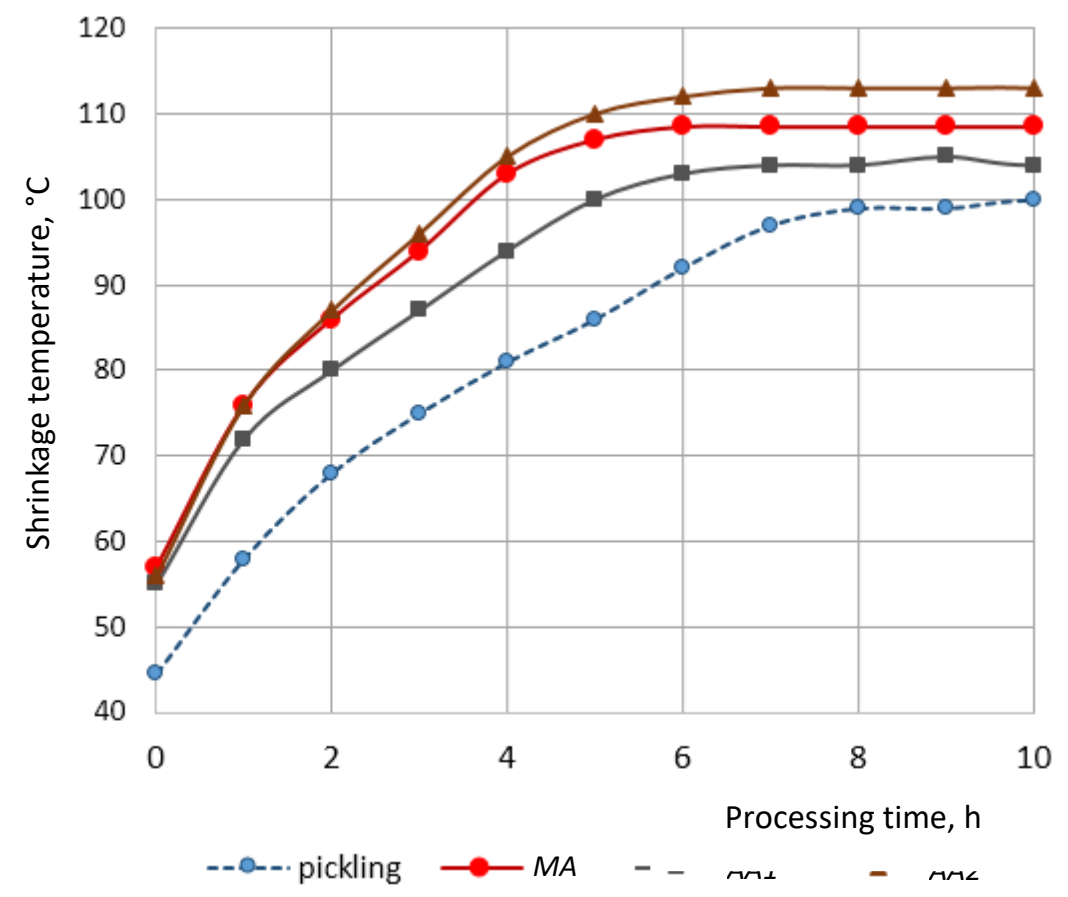

Figure 1. Influence of pretanning treatment on the dynamics of shrinkage temperature changing

\section{RESULTS AND DISCUSSIONS}

\section{Research on the Process of Pickling-Free Chrome-Polymeric Tanning}

We have found that as compared with the common chrome-pickling technology, picklingfree chrome-polymeric tanning using the product $A A 2$ allows us to lower the consumption of chrome tanning agents by $25 \%$, as well as improve consumer properties and cutting qualities of the finished leather product. In addition, durability limit increases by $13.0 \%$, the yield of thickness - by $4.2 \%$, vapour permeability by 2.0 times, the yield of area by $1.5 \%$, grade of quality by $0.5 \%$. Furthermore, as a result of decreasing the tanning process length by 2.5 times and decreasing the chrome compounds content in discharged chrome-containing solutions by 2.0 times, as well of lowering the content of sulphates by 1.5 times, chlorides by 1.2 times, $\mathrm{BOD}_{5}$ by 2.0 times, $\mathrm{COD}$ by 1.2 times the ecological and energetical load on the environment also goes down [34].

In order to find how polymeric processing influences the structure formation and a tanning agent spread uniformity in the structure of the semi-finished product Wet-blue we have applied scanning electronic microscopy during the experiment.

The figure $2 a$ shows, that the manner of interlacing of collagen bundles is weak to be noticed on the semi-finished product of chromepickling tanning cross-section. Moreover, the voids distribution in the cross-section area is uneven. The uneven distribution of the collagen secondary fibers (bundles) is connected with uneven diffusion of the chrome tanning agent in the derma. In the microphotos of the crosssection of the semi-finished product of the chrome-polymeric tanning we have found a more dense structure. This could be the result of creating more favourable conditions for the diffusion and fixation of tanning chrome compounds in the derma when using polymeric compounds (figure $2 b$ ). Further analysis of the semi-finished product (chrome-polymeric tanning) cross-section microphotos showed more even spread of collagen fibers bundles and more distinct uniformity of interfascicular spaces location in the derma. 


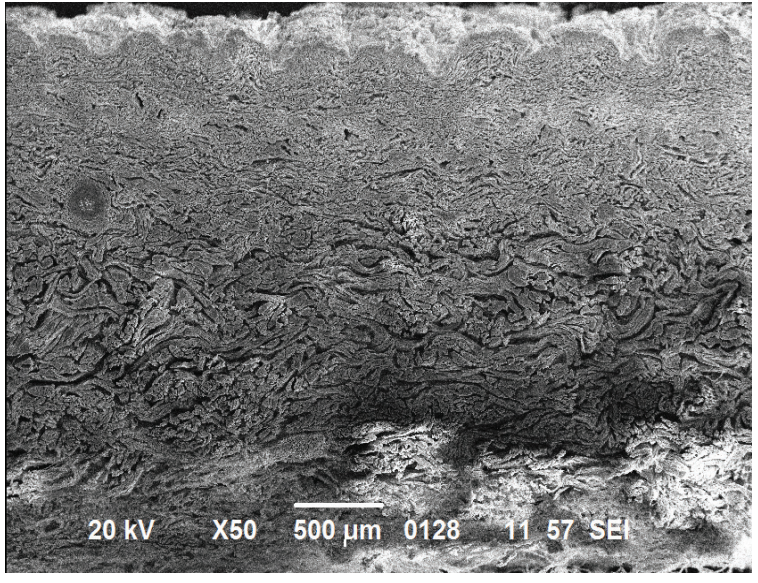

a

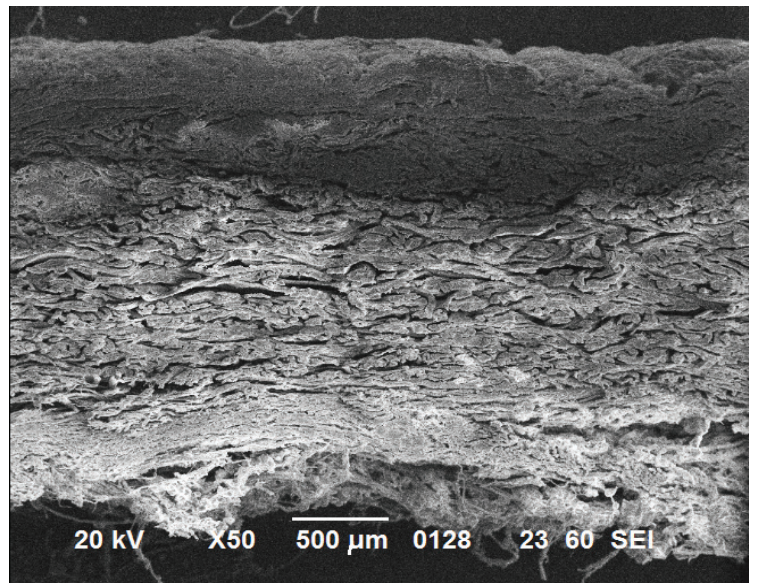

$b$

Figure 2. Microphotos or the derma cross section: chrome-pickling $(a)$ and chrome-polymeric tanning $(b)$

The microscopic research done on the microstructure of the derma of the semi-finished product of the chrome-pickling tannage shows that the combined use of polymeric and tanning chrome compounds improves diffusion and the uniformity of the tanning agent spread in the derma. This, in turn, must have a positive impact on the structure formation and the properties of the leather semifinished product and the finished leather product.

\section{Crusting Processes Development for the Chrome-Polymeric Tanned Leather Using Polymeric Compounds}

The aim of this stage of our study is to find the opportunity to use the polymeric compounds under study during crusting processes. During this test we have used the leather semi-finished product of the chrome-pickling tanning, which has the following properties: the shrinkage temperature is $123{ }^{\circ} \mathrm{C}$, the mass content of humidity is $33.9 \%$, the mass content of chromium oxide is $5.8 \%$ (per completely dry substance), the average thickness is $2.2 \mathrm{~mm}$. The liquid finishing has been performed using the following procedure [35] and the following scheme: washing-neutralization-washingpolymeric processing-dying-fatting-retanning. In addition, the polymeric processing has been performed before dying and using a polymeric compound in the form of MA product. The processing conditions (or parameters) are given in the (table 1).

Table 1: Liquid finishing conditions of the semi-finished product of the chrome-pickling tanning

\begin{tabular}{ccccc}
\hline \multirow{2}{*}{ Group } & \multicolumn{3}{c}{ Consumption, \% } & \\
\cline { 2 - 4 } & $M A$ & anionic brown & quebracho tannins & Temperature, ${ }^{\circ} \mathrm{C}$ \\
\hline 1 & 6.0 & 2.0 & 2.0 & 50 \\
2 & 1.0 & 2.0 & 2.0 & 50 \\
3 & 6.0 & 1.0 & 2.0 & 50 \\
4 & 1.0 & 1.0 & 2.0 & 50 \\
5 & 6.0 & 2.0 & 2.0 & 30 \\
6 & 1.0 & 2.0 & 2.0 & 30 \\
7 & 6.0 & 1.0 & 2.0 & 30 \\
8 & 1.0 & 1.0 & 2.0 & 30 \\
Control & - & 2.0 & 4.0 & 40 \\
\hline
\end{tabular}


There have not been any complications when using polymeric processing before dying. The finished leather had distinct appearance, as the surface was dyed evenly, they were also soft to the touch, filled, they had pleasant feel. Moreover, we have found that the dye penetrated the derma more deeply.

The results of physico-chemical tests of the leather proved their high hydrothermal resistance (at least $125{ }^{\circ} \mathrm{C}$ ), durability and excellent plastic-elastic properties, even spread of components in the derma structure. These factors influence positively the yield of area of the leather, as well as the even spread of the durability and elongation to different sides indices. This, in turn, promotes the cutting effectiveness (table 2).

Table 2: The influence of crusting processes using polymeric compounds on the crust leather of the chrome-polymeric tanning properties

\begin{tabular}{|c|c|c|c|c|c|c|c|c|c|}
\hline \multirow{2}{*}{ Index } & \multicolumn{9}{|c|}{ Group } \\
\hline & 1 & 2 & 3 & 4 & 5 & 6 & 7 & 8 & Control \\
\hline Tensile strength, $\mathrm{MPa}$ & 27.9 & 30.4 & 30.6 & 26.0 & 19.8 & 21.2 & 22.0 & 22.4 & 26.6 \\
\hline Strength of surface, $\mathrm{MPa}$ & 21.7 & 27.7 & 23.1 & 19.9 & 13.4 & 15.9 & 13.7 & 14.8 & 16.2 \\
\hline Percentage extension at $10 \mathrm{MPa}, \%$ & 38.5 & 38.0 & 31.0 & 33.5 & 42.0 & 41.5 & 40.0 & 42.0 & 41.5 \\
\hline Porosity, \% & 45.5 & 50.0 & 53.9 & 51.0 & 55.4 & 54.6 & 54.0 & 47.1 & 42.1 \\
\hline Vapour permeability, \% & 925 & 73.9 & 87.1 & 62.3 & 94.2 & 88.3 & 85.2 & 78.5 & 69.5 \\
\hline Staining by dye, \% & 80.5 & 61.1 & 80.9 & 74.1 & 95.8 & 57.4 & 76.2 & 49.9 & 66.6 \\
\hline Yield of: thickness, $\%$ & 99.0 & 100.0 & 92.8 & 91.5 & 100.0 & 92.5 & 91.0 & 94.4 & 92.1 \\
\hline area, \% & 93.4 & 96.7 & 96.7 & 93.5 & 91.8 & 88.6 & 94.7 & 93.4 & 93.3 \\
\hline volume, $\mathrm{cm}^{3} / 100 \mathrm{~g}$ of protein & 233 & 236 & 217 & 208 & 230 & 199 & 233 & 211 & 231 \\
\hline Generalized objective function $\mathrm{Y}, \mathrm{r}$ & 0.05 & 0.07 & 0.05 & 0.08 & 0.07 & 0.09 & 0.05 & 0.08 & 0.10 \\
\hline
\end{tabular}

The positive influence of polymeric processing on other crust leather properties are also worth mentioning. For example, the following properties of the groups under study have been improved as compared with those of the control group: porosity (at $22.2 \%$ ), relative vapour permeability (at 13.2\%), the yield of thickness (at $3.3 \%$ ), the yield of area (at $0.3 \%$ ), tensile strength (at $8,1 \%$ ) and strength of surface (at $37.4 \%$ ). Despite the fact that the average volume yield of the specimens under test is lower by $4.5 \%$ than that of the control group, its high level (199-236 $\mathrm{cm}^{3} / 100 \mathrm{~g}$ of protein) means the well-formed derma structure as a result of combining the processes of polymeric processing and dying.
The search for the optimal combination of technology factors, which provides the necessary qualities of the chrome leather, have been conducted using the generalized objective function $Y, r$ [23]. The smaller is the index, the better are the qualities of a leather semifinished product under test. On the basis of the calculations made, we have found that the best leather qualities are formed under the following conditions (group 3): polymers consumption $6.0 \%$, dye consumption $2.0 \%$, the temperature of combined polymeric processing and dying $50{ }^{\circ} \mathrm{C}$, quebracho tannins consumption during retanning 2.0\% $(\mathrm{Y}, \mathrm{r}=0.05)$; in the control group this index is much worse $(Y, r=0.10)$. 
The Unified Production Technology of the Crust Leather Development

All the natural leather production technologies are developed taking into account the aim of the product, and all the products need to undergo preparatory, pretanning-tanning, dying-fatting, drying-moisturising processes and operations, as well as the last, "finishing" stage. The latter means multiple application of the finishing coat on the leather, as well as fixation, pressing, embossment, cutting of the grain etc. The full finishing cycle limits the possibilities of further design and construction of products using modern methods of various technologies. It has to do not only with the complete finishing cycle but also with the impossibility to apply such methods of decoration as engraving, laser processing, painting, monogram, logo imprinting etc. Once the finishing coat is applied to the surface, it has a negative effect on the constructive elements of the corresponding equipment, because it litters the equipment with pigment and polymeric particles. Moreover, when painting or applying a monogram the dyes adhesiveness decreases due to the difference of film-forming agents, and the presence of wax or lacquer film.

Taking into account everything mentioned above, the topical task is to develop a unified technology of leather production excluding surface finishing, i.e. getting the crust leather material, which would make it possible to use this material when producing various goods of various designated use, both decorative and utilitarian. Finishing should be done using modern design methods and biogenous materials.

The results of the tests described above made us think about integrating the technologies of pickling-free chrome polymeric tanning and liquid finishing using polymeric compounds at tanning and dying stages (figure 3 ).
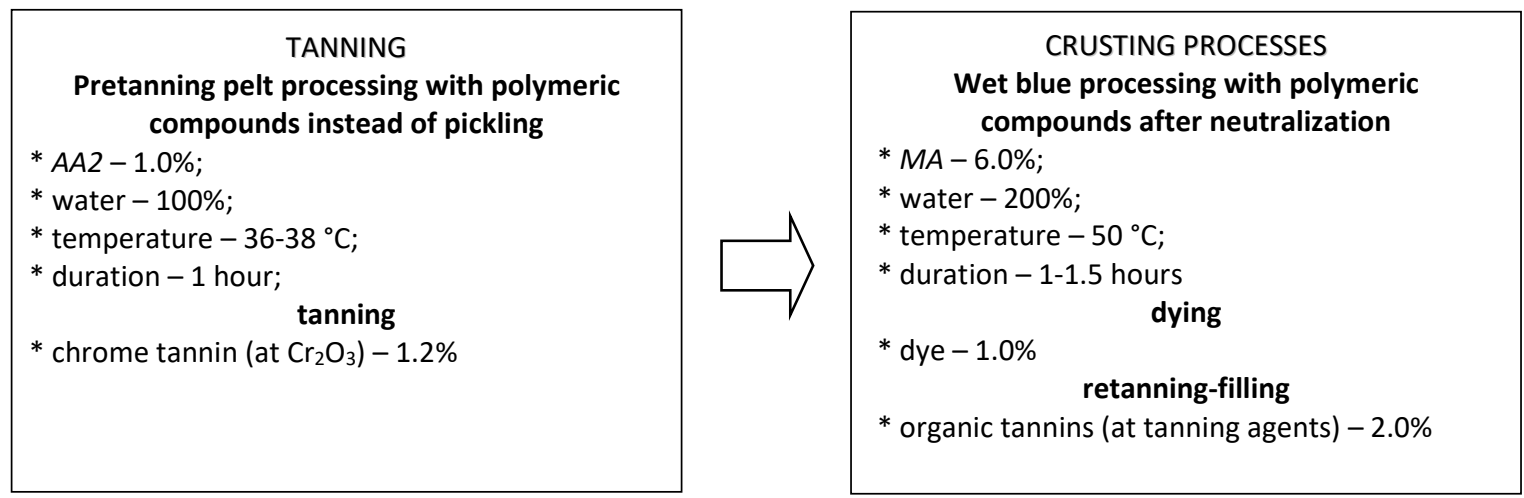

Figure 3. Unified resource-saving technology of the crust leather production using polymeric compounds

After the range of tests, done in laboratories and half-production conditions, we have developed a unified resource-saving technology of the crust leather production using polymeric compounds at the stage of tanning with chrome compounds and the liquid finishing stage (figure 3 , table 3 ).

This technology provides not only the improvement of the quality parameters of leather products due to the more even spread of chemical reagents in the derma structure, increasing and more even spread in different directions of the durability and elongation indices, improving hygienic properties, colour uniformity at daylight, but also promotes the technology processes of tanning and crusting processes intensification, as well as decreases the ecological load on the environment due to more sustainable use of scarce mineral resources such as leather raw materials, dyes, mineral and organic tanning agents. The results obtained could be explained by the fact that the polymeric compounds under study are capable 
Table 3: Comparative assessment of the crust leather production technologies

\begin{tabular}{|c|c|c|}
\hline \multirow[b]{2}{*}{ Index } & \multicolumn{2}{|r|}{ Technology } \\
\hline & unified & $\begin{array}{c}\text { known } \\
\text { (tannery“Chinbar”(Kyiv)) }\end{array}$ \\
\hline Duration of tanning, hours & 4 & 10 \\
\hline $\begin{array}{l}\text { Consumption, \%: } \\
\text { chrome tannin agent (tanning) }\end{array}$ & 1.2 & 1.6 \\
\hline organic tannins (retanning-filling) & 2 & 4 \\
\hline dye (dyeing) & 1 & 2 \\
\hline Exhaution of chrome solution , \% & 85.0 & 73.4 \\
\hline $\begin{array}{l}\text { Mass content, \% (per completely dry substance) } \\
\text { chromium oxide }\end{array}$ & 5.0 & 4.8 \\
\hline substances, extracted with organic solvents & 6.7 & 5.1 \\
\hline Shrinkage temperature, ${ }^{\circ} \mathrm{C}$ & 125.5 & 124.0 \\
\hline Tensile strength, MPa & 2.2 & 2.1 \\
\hline Strength of surface, $\mathrm{MPa}$ & 1.8 & 1.5 \\
\hline Percentage extension at $10 \mathrm{MPa}, \%$ & 38.5 & 39.4 \\
\hline $\begin{array}{l}\text { Yield of: } \\
\quad \text { thickness, } \%\end{array}$ & 93.8 & 92.4 \\
\hline area, $\%$ & 92.3 & 92.0 \\
\hline volume, $\mathrm{sm}^{3} / 100 \mathrm{~g}$ of protein & 233.0 & 231.3 \\
\hline Colouring uniformity $\left(\Delta \mathrm{E}_{\mathrm{D} 65}\right)$ & 1.98 & 7.06 \\
\hline Distribution efficiency of tensile strength & 0.79 & 0.69 \\
\hline Distribution efficiency of strength of surface & 0.70 & 0.61 \\
\hline Distribution efficiency of percentage extension at $10 \mathrm{MPa}$ & 0.89 & 0.72 \\
\hline Relative vapour permeability, \% & 92.5 & 69.5 \\
\hline Grade of quality, \% & 93.9 & 93.1 \\
\hline
\end{tabular}

not only of being sorbed and distributed evenly in the derma structure, due to their structure and properties, but also of interacting with active collagen groups and other chemicals reagents. This leads to the excellent properties of the raw material and the finished product: durability, heat resistance, formedness, plastic-elastic, hygienic, aesthetic and other qualities.

\section{CONCLUSIONS}

The research done shows that there is a rationale for using polymeric compounds based on maleic and acrylic acids, and that they have a positive effect on the structure formation and leather properties. We have found that structuring efficiency, improvement of consumer qualities and aesthetic properties of the latter depend on the chrome tanning agent consumption significantly, as well as on polymeric compounds during the tanning and crusting processes.

We have developed a unified resourcesaving technology of the crust leather production, using polymeric compounds at the stages of tanning and crusting processes. In addition, tanning includes pre-processing of abated pelt with a polymeric compound based on acrylic acid instead of pickling, which allows us to decrease the duration of the process as well as the tanning agent consumption by $25 \%$. The liquid finishing includes using a polymeric compound based on maleic acid after the neutralization process (before dying), which allows us to decrease the processing duration by $20 \%$, dying agents and tannins consumption by $50 \%$, to increase the grade of quality, to increase the crust leather yield of thickness by $1.4 \%$, by area by $0.3 \%$.

\section{REFERENCES}

1. Tegtmeyer, D., Leather Age, 2010, 7, p. 57-58.

2. Saravanan, P., Raghava Rao, J. The Journal of Indian Leather Technologists' Association, 2010, 8, 668-671.

3. Lui, C., Latona, N., Ashby, R., J Am Leather Chem As, 2006, 101, 10, 368-375. 
4. Money, C.A., Babu, N.K.C., Leather International, 2006, 208, 30-32.

5. Robinson, C., Nature and structure of collagen, London: Butterworths, 1953.

6. Casparus, J., Reinhard, V., Products and application of biopolymers, Croatia: InTeh, 2012.

7. Pantazi, M., Stefan, D.S., Constantinescu, R., Anghel, R., Meghea, A., Vasilescu, A.M., Revista de Chimie, 65, 2, 2014, 234-236.

8. Brown, E.M., Taylor, M.M., Marner, W.N., J Am Leather Chem As, 1996, 91, 270-275.

9. Covington, T., Tanning chemistry: The science of leather, RSC publishing, 2009.

10. Gaidau, C., Applicative Chemistry of Tanning Metallic Heterocomplexes: Monograph, Sharjah, 2013, https://doi.org/10.2174/97816 080574361130101.

11. Ludvik, J., Chrome balance in leather processing, United Nations Industrial Development Organization (UNIDO), 2000.

12. Senior, K., World leather, 7, 2000, 51-55.

13. Covington, A.D., J Am Leather Chem As, 1989, 93, 168-183.

14. Sathiyamoorthy, M., Journal of Engineering, Computers and Applied Sciences, 2013, 5, 1722.

15. Zhou, J., J Soc Leath Tech Ch, 2012, 4, 96, 157162.

16. Zhao, Y.T., Wang, X.-C., J Soc Leath Tech Ch, 2007, 91, 246-251.

17. Stuart, B., editor D. J. Ando, Biological application of infrared spectroscopy: University of Grinwich; 1997.

18. Liu, J., Li, X., Wang, W., Xiao, W., Zhang, J., Zhou, Z., J Chem Pharm Res, 2014, 6, 6, 938-941.

19. Sarver, R.W., Krueger, W.C., Anal Biochem, 1991, 194, 89-100, https://doi. org/10.1016/0003-2697(91)90155-M.

20. Schanda, J.D., Colorimetry. Handbook of Applied Photometry: OSA/AIP, 1997.
21. Hamilton, D.K., Wilson, T., Scanning, J Phys E, 1986, 19, 52-54, https://doi. org/10.1088/0022-3735/19/1/009.

22. Gorbachev, A.A., Kerner, A.S., Andreyeva, O.A. et al., Basis for the creation of modern production technologies (in Ukrainian), KNUTD, 2007.

23. Wang, X., Lu, W., Li, Y., Wang, H., J Soc Leath Tech Ch, 2007, 101, 1, 6-9.

24. Wang, X., Guo, X., Wang, H., Linear-hyper branched amphiphilicpoly phosphateesters A novel fatliquor on the leather, Proceedings of the $34^{\text {th }}$ IULTCS Congress: Science and Technology for Sustainability of Leather: Chennai, 2017.

25. Du, J., Huang, C., Peng, B., J Soc Leath Tech Ch, 2016, 100, 2, 67-72.

26. Jaisankar, S.N., Samanta, D., Saravanan, P., Muralidharan, C., Water based polymer nanoclays composite coating rheology for leather applications, Proceedings of the $33^{\text {rd }}$ IULTCS Congress: International Union of Leather Technologists and Chemists: Novo Hamburgo, 2015.

27. Lovato, G., Paganin, M., A novel class of polymeric fatliquors, Proceedings of the $33^{\text {rd }}$ IULTCS Congress: International Union of Leather Technologists and Chemists: Novo Hamburgo, 2015.

28. Yuye, C., Xiangxiang, W., Yunjun, L., Shufen, Z., J Soc Leath Tech Ch, 2010, 94, 5, 200-204.

29. Palor, R., Leather Sci Abstr, 1995, 28, 1, 8.

30. Song, Y. et al., J Am Leather Chem As, 2017, $112,128-134$.

31. Afşar, A., Özgünay, H., Yilmaz, O., Zengin, A.C.A., Zengin, G., Tekstil ve Muhendis, 2013, 20, 89, 21-27, https://doi.org/10.7216/130075992013 208903.

32. El A'mma, A., J Am Leather Chem As, 2000, 95, 1, 19-24.

33. Lukianets, L.A., Andreyeva, O.A., Herald of Khmelnytsky National University, 2009, 4, 137, 208-211. 
34. Nikonova, A., Andreyeva, O., Maistrenko, L., IOP Conference Series: Materials and engineering, 2016, 111, 1, 1-6, https://doi.org/10.1088/1757899X/111/1/012024.

35. Nikonova, A., Andreyeva, O., Maistrenko, L., ICAMS 2016 Advanced Materials and Systems: Proceedings of the 6th International Conference: Bucharest, 2016, 369-374, https://doi.org/10.24264/icams-2016.I.20.
(C) 2019 by the author(s). Published by INCDTPICPI, Bucharest, RO. This is an open access article distributed under the terms and conditions of the Creative Commons Attribution license (http:// creativecommons.org/licenses/by/4.0/). 